\title{
Application of combined process of partial nitritation - anammox using a rotating biological contactor (PARBC) to treat ammonium-rich wastewater.
}

\author{
Nguyen Nhu Hien', Truong Thi Thanh $\operatorname{Van}^{2}$, Le Thanh Son, Phan The Nhat ${ }^{2}$, Nguyen \\ Phuoc Dan ${ }^{2}$. \\ ${ }^{1}$ Institute for Environment and Resources, Ho Chi Minh City University of Technology, Viet Nam \\ ${ }^{2}$ Faculty of Environment and Natural resource, Ho Chi Minh City University of Technology, Viet Nam
}

(Received 15 September 2016, accepted 20 November 2016)

\begin{abstract}
Combining the partial Nitritation and Anammox using a rotating biological contactor $(P A R B C)$ to remove the ammonium in wastewater was evaluated in this study. The accumulation of Anammox bacteria on the carrier easily obtained after 5 days operating of sequence batch with synthetic wastewater. Then $A O B$ biomass cultivated in PARBC to complete the process of combining two bacteria in the same reactor for completely autotrophic nitrogen removal. After 60 batches of the operation, highest nitrogen removal rate reached $0.33 \mathrm{~kg} \mathrm{~N} / \mathrm{m}^{3} . d$ with nitrogen removal efficiency is $90 \%$ at a concentration of ammonium input of $250 \mathrm{mg} \mathrm{N} / \mathrm{L}$. The specific
\end{abstract}

Anammox activity (SAA) of biofilm and suspended sludge in the tank is determined to be $0.298 \mathrm{gN}-\mathrm{N}_{2} / g V S S / d a y$ and $0.0041 \mathrm{gN}$ $\mathrm{N}_{2} / g V S S / d a y$, respectively. Moreover, the suspended sludge concentration is $17.765 \mathrm{mg}$ MLSS/L. This result showed that Anammox bacteria adapt and grow on the rotating biological carrier; otherwise Anammox bacteria hardly develop in the form of suspended sludge in the tank. This study shows that the PARBCR has great potential to effectively removing ammonium from wastewater with the short startup time.

Keywords: Partial nitritation, Anammox, PARBC, ammonium- rich wastwater

\section{INTRODUCTION}

The CANON (Complete Autotrophic Nitrosomonas and the anaerobic process is by Nitrogen Removal Over Nitrite) process is the combination of partial nitritation and anammox in one reactor [1]. This process can be used to remove a high load of ammonia without using external organic carbon [2]. According to Strous et al., 1997 [1], Partial Nitritation process in CANON using two autotrophic group of bacteria (aerobic and anaerobic) provided with limited oxygen. The aerobic process occurs by

Planctomycete bacteria. Those bacteria consumes ammonia and nitrite to produce nitrogen gas and a small amount of nitrate. The CANON reactor is mixed by air flow. The study points out that CANON granular sludge is formed by Amonia Oxydizing bacteria (AOB) in the surface and Anammox bacteria in the core. 
Similar to CANON, the SNAP (Single Stage Nitrogen Removal Using Anammox And Partial Nitritation) was used for nitrogen removal based on partial nitritation and anammox in one reactor. The differences between those two were the using of acrylic medium for attached AOB and anammox [3]. Those bacteria are in charge of the transformation of ammonia to nitrogen gas. SNAP has advantages in wastewater treatment practice because the process is more stable and reduce sludge loss.

Both processes have abilities to remove ammonia via two bacteria group $A O B$ and Anammox. The processes can be summarize as the following equation [4]:

$\mathrm{NH}_{4}^{+}+0.85 \mathrm{O}_{2} \rightarrow 0.435 \mathrm{~N}_{2}+0.13 \mathrm{NO}_{3}^{-}+1.3 \mathrm{H}_{2} \mathrm{O}+1.4 \mathrm{H}^{+}$

This study treated ammonia by the combining process of partial nitrification Anammox in the same reactor. There were the advantages of both CANON and SNAP processes. Using rotation biological contactor (PARBC) to enrich the biomass as SNAP process while supplying gas to mix suspended sludge, increasing exposure and ensuring the necessary concentration of DO in the reactor as CANON process. By which researching the biomass enriching and Anammox-AOB adaptation to evaluate nitrogen removal effectivity of PARBC model and identify SAA.

\section{MATERIALS AND METHODS}

\section{PARBC reactor}

Firgure 1a presents the schematics of PARBC reactor. The reactor is an acrylic column with $(\mathrm{DxH}) 300 \times 640 \mathrm{~mm}$, working height of $530 \mathrm{~mm}$, working volume of $35 \mathrm{~L}$. The reactor was equipped with a mechanical stirrer to ensure complete mixing. The biomass carrier used in this study is shown in Fig.1b.

Polyester biomass carrier (Fig.1b) included 32 sheets (Length $x$ Wide $x$ Thick: 100x85x10mm) and 16 sheets (Length $\mathrm{x}$ Wide $\mathrm{x}$ Thick: 100x50x10mm). This Carrier mounted on a rotating system (Fig.1c) divided into 4 layer (Fig.1b).

In the start-up phase, DO of the feed wastewater was controlled under $0.5 \mathrm{mg} / \mathrm{L}$ using $\mathrm{Na}_{2} \mathrm{SO}_{3}$. $\mathrm{pH}$ was maintaned $6.8-7.0$ using $\mathrm{HCl}$ and $\mathrm{NaHCO}_{3}$ [5]. In the main operating phase, DO was controlled $0.8-1.2$ using DO controller (WTW, Germany) and $\mathrm{pH}$ was maintained between $7.0-7.5$ by $\mathrm{pH}$ controller (WTW, Germany). The PARBC was operated in batch mode. The cycle includes: 15 minutes feed, 45 minutes settling, 15 minutes discharge. The aeration time varies between each tests. 

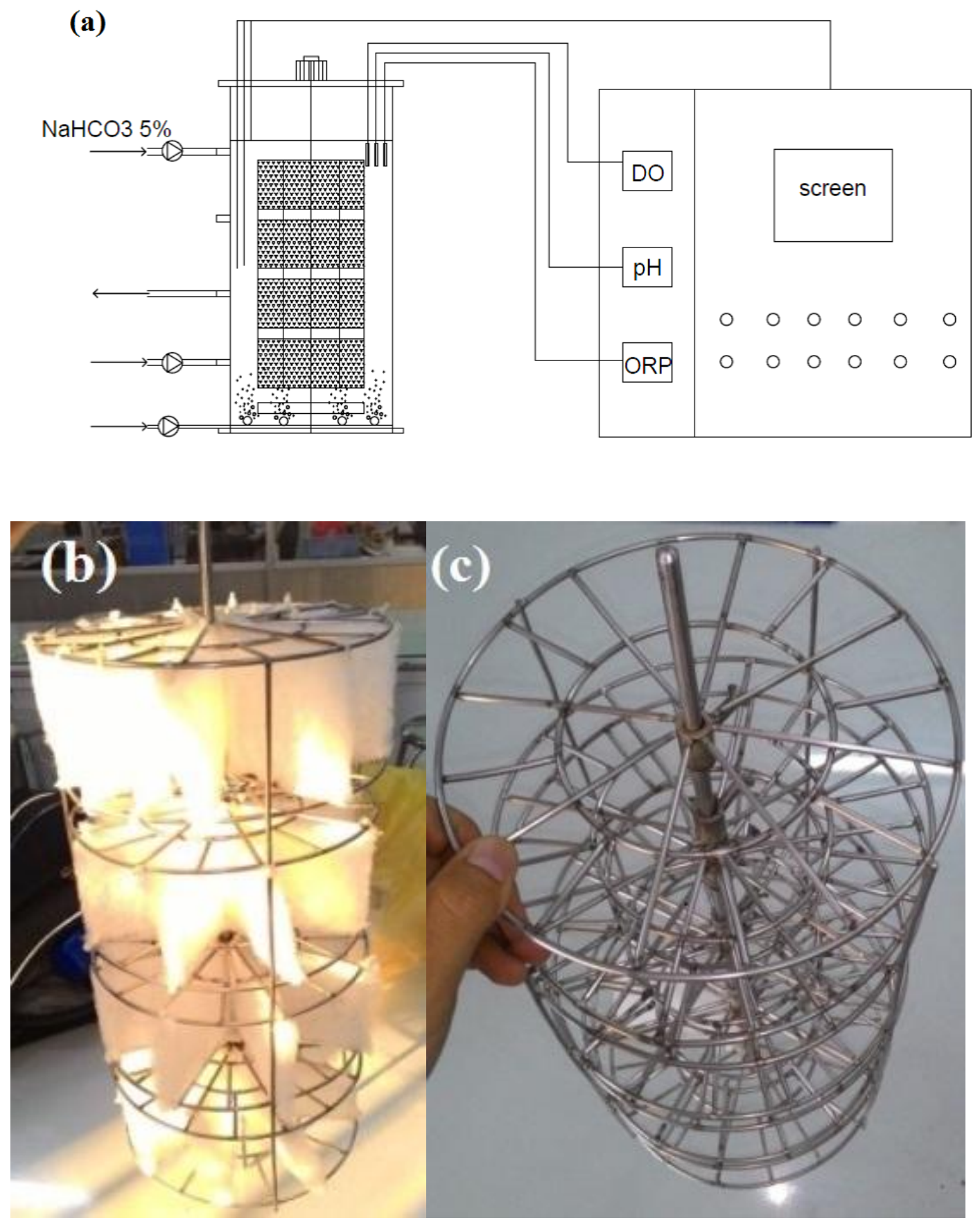

Figure 1. (a) PARBC schematics (b) Biomass carrier (c) Rotating system

\section{Sludge and wastewater}

In the attached phase using synthetic wastewater, $90 \mathrm{~g}$ granular anammox sludge taken from the IC reactor in Laboratory of
FENR - HCMUT was injected into PARBC reactor [5]. This granular sludge has VSS/SS = 0.6 and SAA $=0.58 \mathrm{~g} \mathrm{~N}_{2} / \mathrm{VSS}$.h. The reactor media was rotated at $10 \mathrm{rpm}$ for mixing and 
attaching sludge without aeration. The HRT, not including feed, settled and discharge time, was 360 minutes. One cycle is 435 minutes long. At the end of the cycle, the wastewater was sampled and analyzed to measure $\mathrm{NH}_{4}-\mathrm{N}, \mathrm{NO}_{2}$ $\mathrm{N}$, NO3- -N. Based on the collected data, nitrogen removal efficiency and anammox activity were accessed. When the nitrogen removal efficiency reach $90 \%$, the sludge was sampled and analyzed to measure MLSS, MLVSS, SVI30, SAA. After that, the attached phase was ended.

$\mathrm{NH}_{4} \mathrm{Cl}(20-125 \mathrm{mgN} / \mathrm{L})$ and $\mathrm{NaNO}_{2}(20$ $125 \mathrm{mgN} / \mathrm{L}$ ) were used as substrate for the synthetic water in this phase. The micronutrients comprises of: $500 \mathrm{mg} / \mathrm{L} \mathrm{KHCO}_{3}, 54 \mathrm{mg} / \mathrm{L}$ $\mathrm{KH}_{2} \mathrm{PO}_{4}, 360 \mathrm{mg} / \mathrm{L} \quad \mathrm{CaCl}_{2} .2 \mathrm{H}_{2} \mathrm{O}, 120 \mathrm{mg} / \mathrm{L}$ $\mathrm{MgSO}_{4} \cdot 7 \mathrm{H}_{2} \mathrm{O}$ [6].

In the main operation phase, the $\mathrm{AOB}$ sludge was injected into PARBC reactor. $90 \mathrm{~g}$ of AOB sludge was taken from the pilot PNSBR reactor in Laboratory of FENR - HCMUT. This granular sludge has $\mathrm{VSS} / \mathrm{SS}=0.76, \mathrm{SAA}=$ $8.88 \mathrm{~g} \mathrm{~N}_{2} /$ VSS.h, SVI $-40 \mathrm{ml} / \mathrm{g}$.

$\mathrm{NH}_{4} \mathrm{Cl}$ (250 mg N/L) was used as substrate for the synthetic water in this phase. The micronutrients comprises of: $1000 \mathrm{mg} / \mathrm{L}$ $\mathrm{KHCO}_{3}, \quad 54 \mathrm{mg} / \mathrm{L} \quad \mathrm{KH}_{2} \mathrm{PO}_{4}, \quad 360 \quad \mathrm{mg} / \mathrm{L}$ $\mathrm{CaCl}_{2} .2 \mathrm{H}_{2} \mathrm{O}, 120 \mathrm{mg} / \mathrm{L} \mathrm{MgSO}_{4} .7 \mathrm{H}_{2} \mathrm{O}$ [6].

\section{Specific activity of Anammox sludge (SAA)}

\section{Attached sludge}

The specific activity of Anammox was measured using the pressure method according to Dapena - Mora A., 2006 [7]. The AutomaticHigh-Sensitivity-Gas-Metering-Systems (AHSGMS) consists of an erlen, a pressure meter connected with PC via DAQMaster sofware for continuously monitoring (Firgure 2). The sludge was taken from $16 \mathrm{~cm}^{2}$ of PARBC media and then washed by phosphate solution $\left(0,14 \mathrm{~g} / \mathrm{L} \mathrm{KH} \mathrm{KH}_{2} \mathrm{PO}_{4} ; 0,75 \mathrm{~g} / \mathrm{L} \mathrm{K} 2 \mathrm{HPO} 4\right)$ [7] before feeding into the erlen with $63 \mathrm{ml}$ synthetic water. The experiments were conducted with 3 different sludge samples in 3 different compartments of the reactor. The tests were done in room temperature and $150 \mathrm{rpm}$ mixing speed by magnetic stirrer. The SAA values ( $\mathrm{gN}-\mathrm{N}_{2} / \mathrm{gVSS} /$ day) were calculated based on the nitrogen gas production rate which was determined through the increase of gas pressure in the erlen.

\section{Suspended sludge:}

$100 \mathrm{ml}$ suspended sludge in PARBC was taken and washed with tap water. $0.126 \mathrm{~g}$ VSS (dry weight) was feed into the erlen. The experiment were conducted similarly as to the one with attached sludge. 


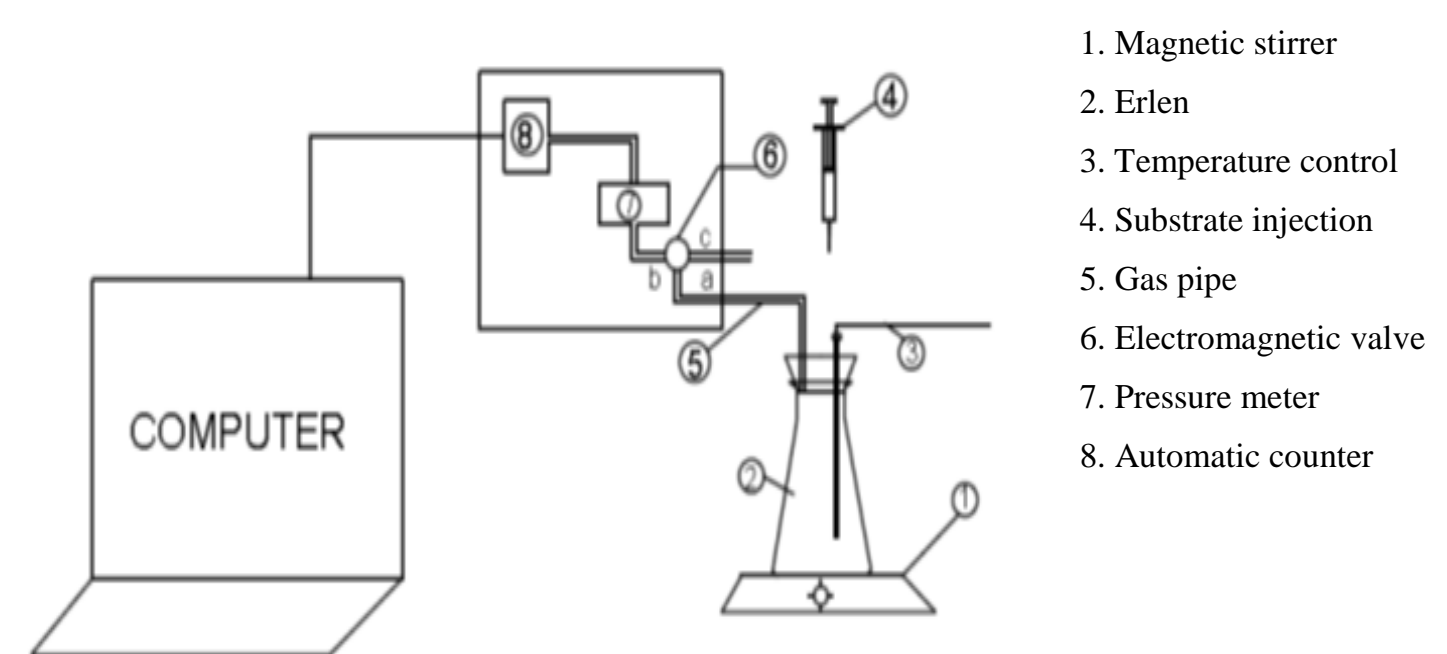

Figure 2. AHSGMS schematics

\section{Denitrification specific activity}

The sludge was taken from $16 \mathrm{~cm}^{2}$ media and then washed with Mineral medium 5 times to eliminate the remaining ammonia and nitrite. This medium contained (per 1 demineralized water): $\left(\mathrm{NH}_{4}\right)_{2} \mathrm{SO}_{4} 330 \mathrm{mg} ; \mathrm{NaNO}_{3} 345 \mathrm{mg}$; $\mathrm{KHCO}_{3} \quad 500 \quad \mathrm{mg} ; \quad \mathrm{KH}_{3} \mathrm{PO}_{4} \quad 27.2 \quad \mathrm{mg}$; $\mathrm{MgSO}_{4} 7 \mathrm{H}_{2} \mathrm{O} 300 \mathrm{mg} ; \mathrm{CaCl}_{2} .2 \mathrm{H}_{2} \mathrm{O} 180 \mathrm{mg}$ [6]. The solution of synthetic water contained $25 \mathrm{mg}$ $-\mathrm{NO}_{3}-\mathrm{N} / \mathrm{L}$ and washed sludge were feed into the erlen. The liquid was continuosly mixed and sampled in $2 \mathrm{~h}, 4 \mathrm{~h}, 6 \mathrm{~h}, 8 \mathrm{~h}$ for analyzing denitrification specific activity.

\section{Analysis method}

$\mathrm{NO}_{2}-\mathrm{N}$ and $\mathrm{NO}_{3}-\mathrm{N}, \mathrm{NH}_{4}-\mathrm{N}, \mathrm{SS}$, MLSS, MLVSS were determined according to Standard Methods for examination of Water and Wastewater (APHA, 1995). pH and DO were monitored by $\mathrm{pH}$ meter (WTW, Germany) and DO meter (WTW, Germany).

\section{RESULTS AND DISCUSSION}

Start-up and enrichment of Anammox sludge

The start-up time is 28 days long (28 batches). After the first 5 days, most of the sludge was observed to be attached to the media (Figure 3). The same result could be achieved in SNAP reactor by Dien et al.2013 [8] but with longer operation time of 21 days. This happens due to the rotation of $20 \mathrm{rpm}$ in the reactor which allows the anammox sludge to attach easily to the media compared to the SNAP reactor. Figure 4 shows that the concentrations of ammonia and nitrite in the effluent decrease overtime and stay between $12-20 \mathrm{mg}$ N/L, corresponding to removal efficiency of over $90 \%$, after 17 days. 

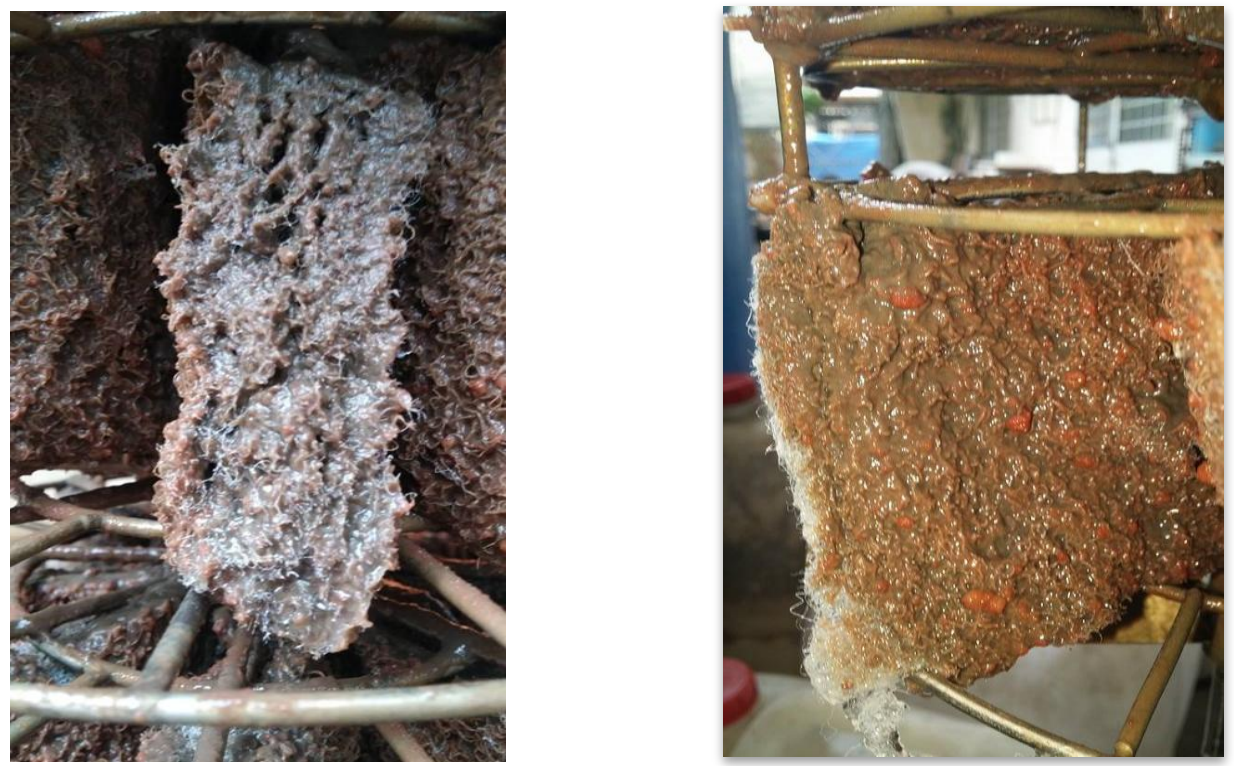

Figure 3. Media sludge after enrichment

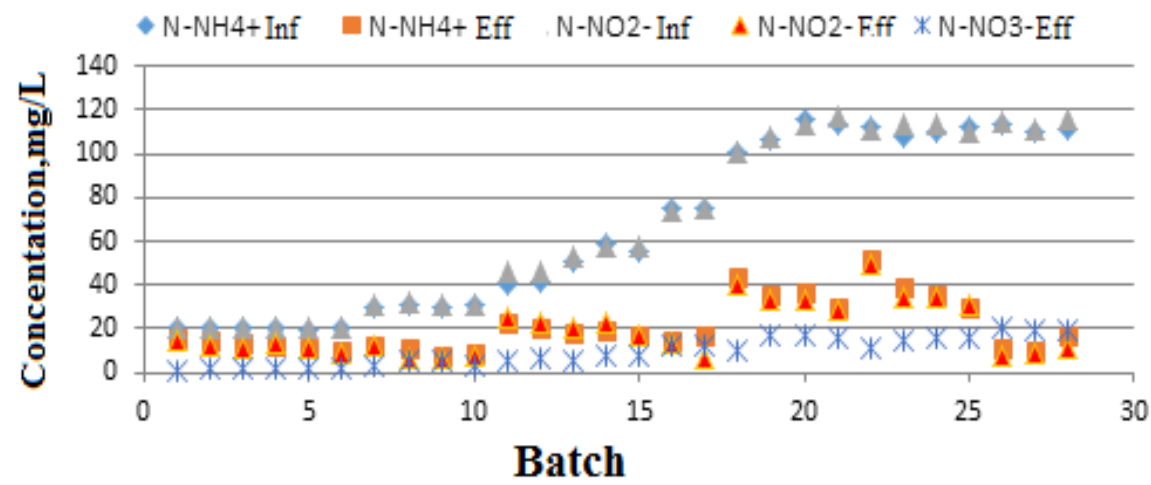

Figure 4. Influent and Effluent nitrogen compounds concentration in anammox acclimation period

\section{Ammonia removal efficiency of PARBC}

After start-up phase for attached anammox, the AOB sludge was feed into the reactor. PARBC was operated for 60 batches. The first 5 batches shows low removal efficiency. After 2 days running, most of the AOB sludge was attached to the media. DO was controlled between $0.8-1.2 \mathrm{mg} \mathrm{O}_{2} / \mathrm{L}$ for AOB activity and reducing anammox inhibition. Figure 5 presents the nitrogen concentration course in the combined phase of anammox and AOB. After 60 batches, the combined partial nitritation and anammox process achieved a ammonia removal of $100 \%$ and nitrogen removal of $90 \%$. A brown and occasionally red layer were observed on the attached sludge that suggests good condition of both $\mathrm{AOB}$ and anammox. $\mathrm{pH}$ in the first 25 batches was controlled at 7 and the next 35 batches was at 7.5. The ammonia removal

\section{Trang 10}


efficiency of PARBC was high and remained unchanged in both $\mathrm{pH}$ levels. The results shows that nitrate concentration of the effluent was always under $15 \mathrm{mg} \mathrm{N} / \mathrm{L}$. According to the theory, the CANON process should produce an effluent nitrate of $13 \%$ total influent ammonia (32.5 mg N/L in this study). This proves that a part of the produced nitrate was converted by the denitrification bacteria. This means there is a community of denitrification bacteria existed in the reactor along with $\mathrm{AOB}, \mathrm{NOB}$ and Anammox. However, the nitrite concentration of the effluent remained high (30-60mg N/L). While the ammonia was mostly consumed, the nitrite concentration was still high. This leads to insufficient substrate (ammonia) for anammox bacteria. The solution is to lower the DO concentration in PARBC in order to provide suitable condition for the growth of anammox bacteria.

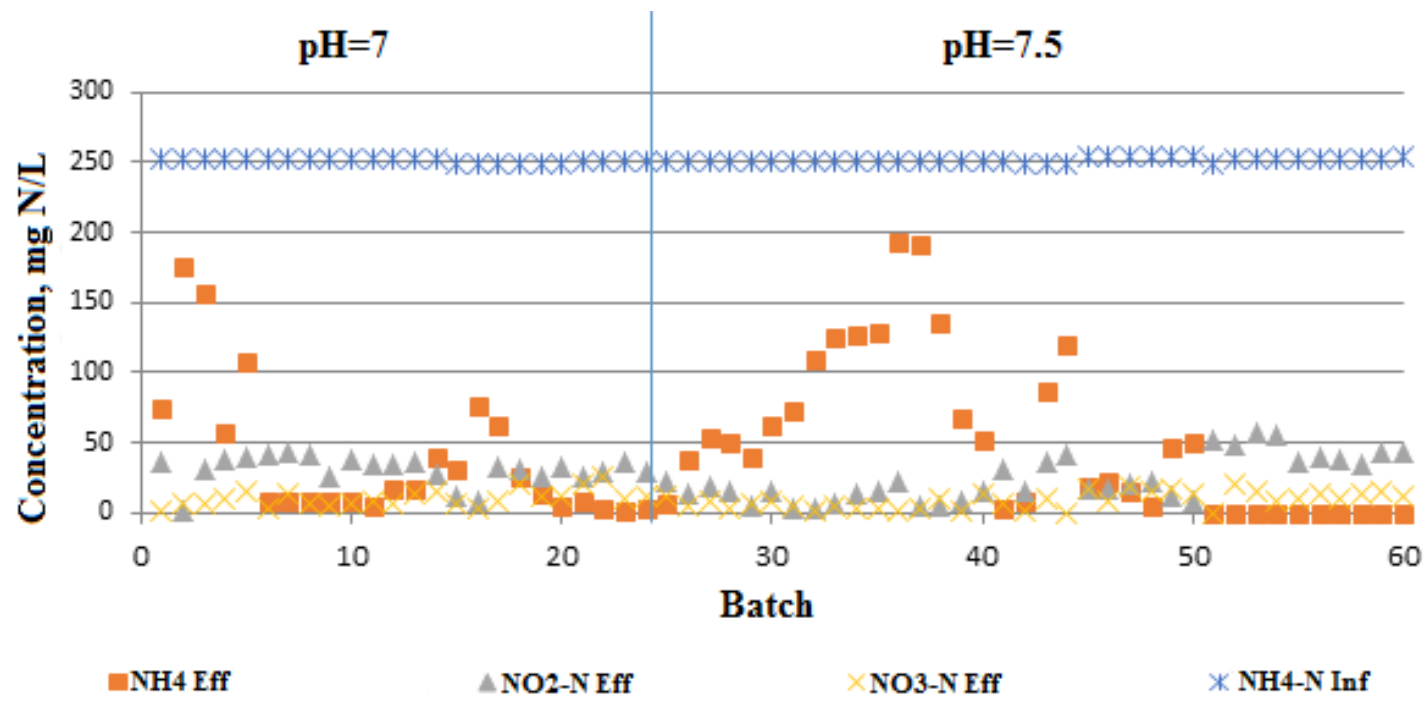

Figure 5. Influent and Effluent nitrogen compounds concentration in anammox and AOB sludge acclimation period 


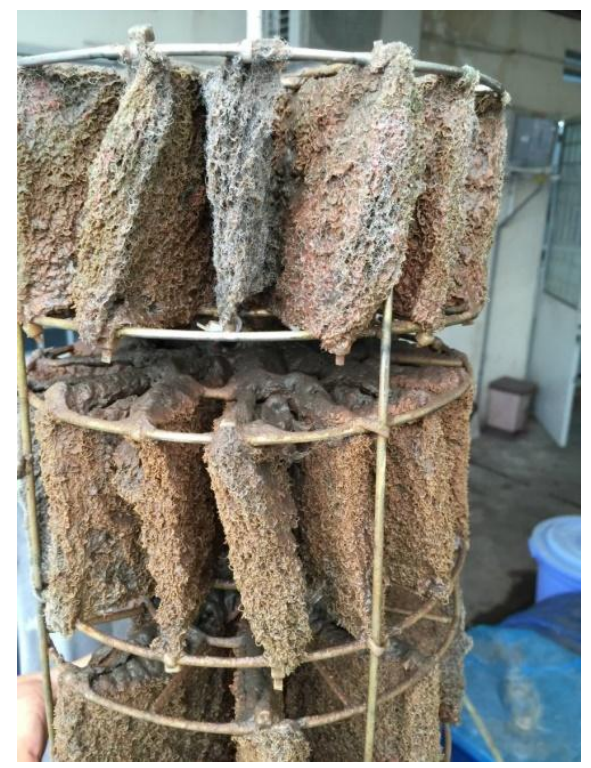

A) $\mathrm{pH} 7$

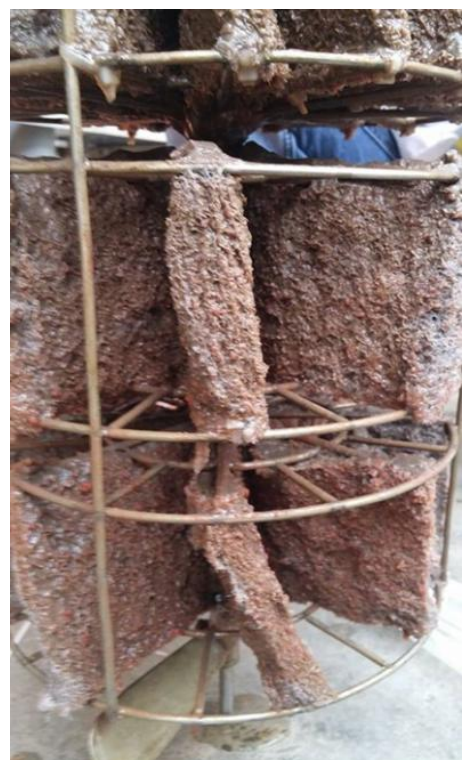

B) $\mathrm{pH} 7.5$

Figure 6. Media in different operation

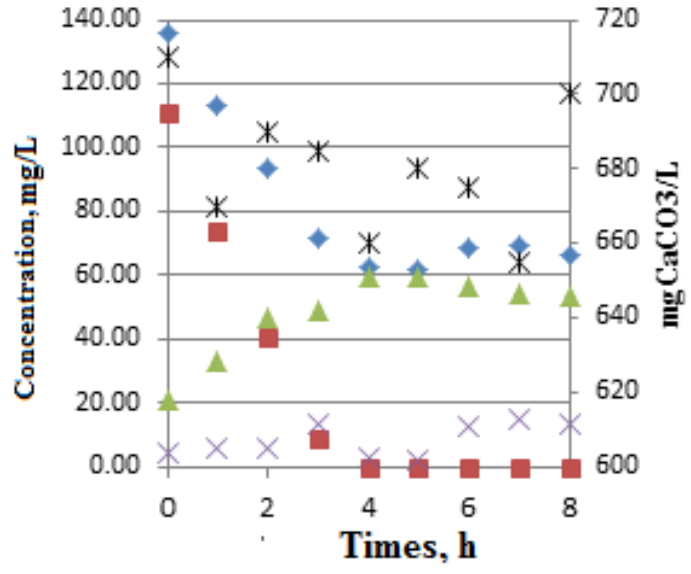

$\rightarrow \mathrm{TN}=\mathrm{N}-\mathrm{NH} 4+\quad \triangle \mathrm{N}-\mathrm{NO2}-\quad \times \mathrm{N}-\mathrm{NO}-\quad *$ Alkality

Figure 7. Variations in the concentration of nitrogen compounds per hour in a batch $(\mathrm{DO}=0,8-1,2)$

Experiments to evaluate the nitrogen balance in the reactor overtime were conducted at $2 \mathrm{DO}$ range of $0.8-1.2$ and $0.4-0.8$. Figure 7 presents the nitrogen removal process in 8 hours at DO equals $0.8-1.2 \mathrm{mg} / \mathrm{L}$. Total

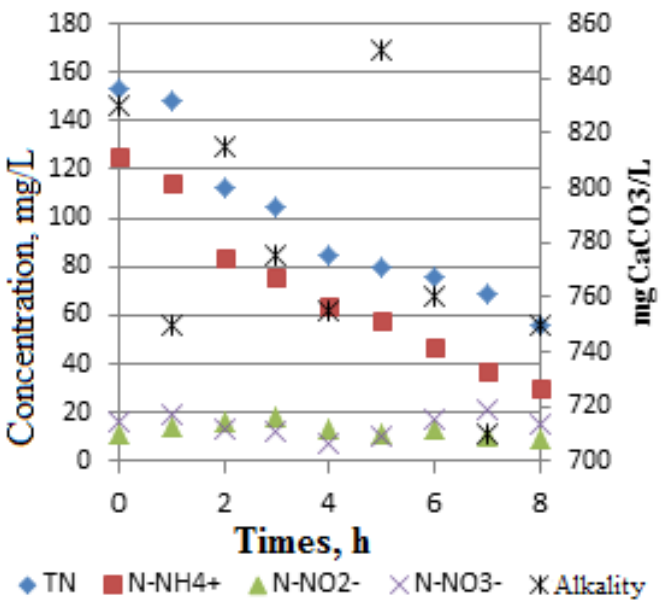

Figure 8. Variations in the concentration of nitrogen compounds per hour in a batch $(\mathrm{DO}=0.4-0.8)$

alkalinity consumed in one batch was 950 $\mathrm{mgCaCO}_{3} / \mathrm{L}$. In the first 4 hours, ammonia was completely removed which shows good activity of AOB. At this time, nitrite concentration was $60 \mathrm{mg} / \mathrm{L}$ and gradually decreased by $10 \mathrm{mg} \mathrm{N} / \mathrm{L}$,

\section{Trang 12}


and nitrate increased by $10 \mathrm{mgN} / \mathrm{L}$. This proves that between $4 \mathrm{~h}$ and $8 \mathrm{~h}$, NOB was the dominant specie in the reactor, AOB and anammox activities were constrained due to insufficient of ammonia. In the next experiment (Figure 8), DO was controlled at low level $(0.4-0.8 \mathrm{mg} / \mathrm{L})$. The ammonia concentration decrease from 125 $\mathrm{mg} / \mathrm{L}$ to $30 \mathrm{mg} / \mathrm{L}$ after $8 \mathrm{~h}$. The results shows that low DO affect the activity of AOB. The concentration of nitrate was $20 \mathrm{mg} / \mathrm{L}$ and remained stable; alkalinity consumed was 720 $\mathrm{mg} \mathrm{CaCO}_{3} / \mathrm{L}$. Table 1 presents the comparison of ammonia and total nitrogen removal rate between this study and others using CANON and SNAP. The result shows that the ammonia and total nitrogen removal rate of PARBC is higher than other study. The PARBC showed great potential in treating ammonia-rich wastewater.

Table 1. Comparison with other studies

\begin{tabular}{|c|c|c|c|c|c|c|}
\hline \multirow[b]{2}{*}{ System } & \multirow{2}{*}{$\begin{array}{c}\text { NLRs } \\
\left(\operatorname{kg~N} / \mathrm{m}^{3} / \mathrm{d}\right)\end{array}$} & \multicolumn{2}{|c|}{ Ammonia removal } & \multicolumn{2}{|c|}{ Nitrogen removal } & \multirow[b]{2}{*}{ References } \\
\hline & & $\underset{\mathrm{kgN} / \mathrm{m}^{3} / \mathrm{d}}{\mathrm{ACE}}$ & $\mathbf{H \%}$ & $\begin{array}{c}\mathrm{NRE} \\
\mathrm{kgN} / \mathrm{m}^{3} / \mathrm{d}\end{array}$ & $\begin{array}{c}\mathrm{H \%} \\
\text { Efficiency }\end{array}$ & \\
\hline PARBC & 0.37 & 0.37 & 100 & 0.33 & 90 & This study \\
\hline $\begin{array}{l}\text { CANON } \\
\text { (SBR - air } \\
\text { pulsing) }\end{array}$ & 0.53 & 0.25 & 47.2 & 0.45 & 85 & [9] \\
\hline $\begin{array}{c}\text { Canon } \\
\text { (SBBR) }\end{array}$ & 0.09 & 0.08 & 88.9 & 0.072 & 80 & [10] \\
\hline $\begin{array}{l}\text { Canon } \\
\text { (SBR) }\end{array}$ & 0.22 & 0.11 & 50 & 0.08 & 36.36 & [4] \\
\hline CANON & 1.5 & 1.26 & 84 & 1.09 & 73 & [11] \\
\hline SNAP & 0.94 & 0.47 & 50 & 0.83 & 88.3 & [12] \\
\hline
\end{tabular}

\section{Nitrate removal rate}

It was found that the denitrification bacteria existed in PARBC reactor. This experiment was conducted to measure the nitrate removal. Figure 9 shows the nitrate removal rate in 8 hours. In the first 2 hours, the removal rate of the attached sludge was $5.78 \mathrm{mg} \mathrm{NO}_{3}-\mathrm{N} / \mathrm{L} . \mathrm{h}$ and the suspended sludge was 7.5 times lower. From 2nd hour to 4th hour, the nitrate removal rate decreased due to the lower of substrate
(COD).This shows that denitrification bacteria mainly existed on the media due to lower DO in media than in suspended matter. The experiments also shows that the nitrate removal rate depends on the concentration of nitrate which is high in the beginning and rapidly reduce toward the end. The denitrification bacteria in the reactor helps improve the treatment efficiency of nitrogen along with COD removal. 


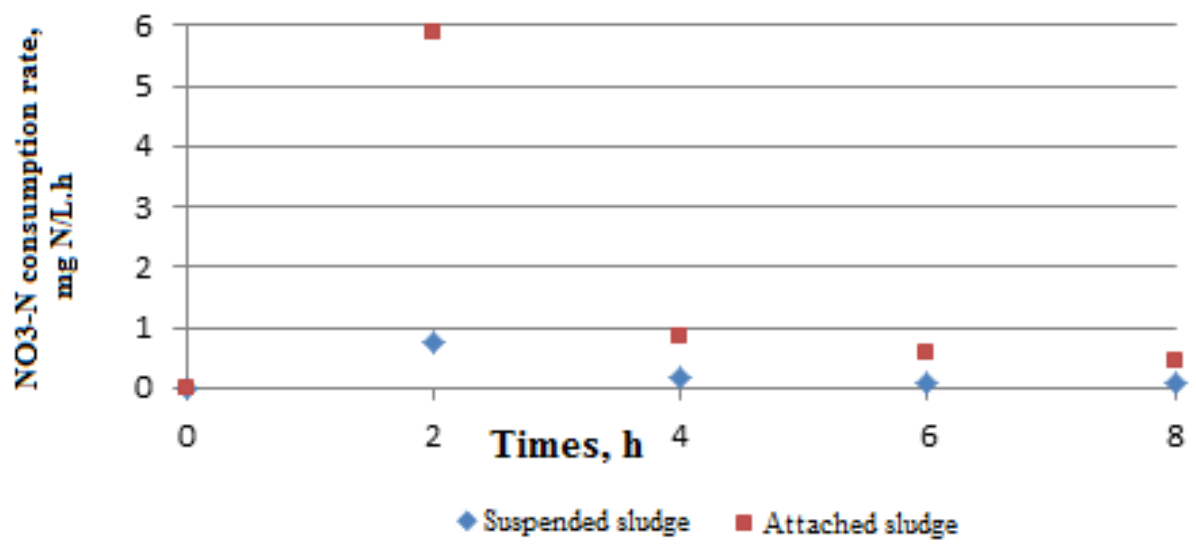

Figure 9. $\mathrm{NO}_{3}-\mathrm{N}$ consumption rate

\section{Biomass}

The MLVSS feed into the reactor in start-up phase was $477 \mathrm{mg} / \mathrm{L}$ (MLVSS/MLSS: 0.6), and increased to $1478 \mathrm{mg} / \mathrm{L}$ after 30 days. After the feeding of $\mathrm{AOB}$, the biomass in the reactor was
$2185 \mathrm{mg} / \mathrm{l}$ (MLVSS/MLSS: 0.76). After 3 months of operation, the biomass concentration in PARBC reactor reach $3.163 \mathrm{mg}$ MLVSS/L. A good growth of both AOB and anammox were observed when using PARBC.

Table 2. MLSS and MLVSS concentrations of PARBC

\begin{tabular}{|c|c|c|}
\hline Parameters & The end of attached Anammox period & The end of experimental period \\
\hline SS $(\mathrm{mg})$ & 2429 & 5076 \\
\hline $\mathrm{VSS}(\mathrm{mg})$ & 1478 & 3163 \\
\hline $\mathrm{VSS} / \mathrm{SS}$ & 0.609 & 0.623 \\
\hline
\end{tabular}

\section{Specific anammox activity (SAA)}

The SAA of attached sludge is $0.298 \mathrm{gN}$ $\mathrm{N}_{2} / \mathrm{gVSS} /$ day and suspended sludge is 0.0041 $\mathrm{gN}-\mathrm{N}_{2} / \mathrm{gVSS} /$ day. The anammox activity of attached sludge is higher than suspended because of DO limitation.

\section{CONCLUSIONS}

This study shows that anammox and AOB were succesfully attached and adapted in PARBC reactor. The high rate of nitrogen removal of $90 \%$ could be easily achieved after 30 days operation. After 60 days running with synthetic wastewater contained $250 \mathrm{mg} \mathrm{NH}_{4}$ $\mathrm{N} / \mathrm{L}$, the removal rate reached $0.37 \mathrm{~kg} \mathrm{~N} / \mathrm{m}^{3} / \mathrm{d}$ corresponding to an ammonia removal efficiency of $100 \%$.
There is evidence that the AOB, NOB, anammox and denitrification bacteria co-existed in the reactor while $\mathrm{AOB}$ and anammox were the main communities to remove nitrogen. The attached anammox community in PARBC is the main contributor to the anammox process with its high activity.

In this study, the concentration of ammonia reached $250 \mathrm{mgN} / \mathrm{l}$ and nitrogen loading rate of $0.37 \mathrm{~kg} \mathrm{~N} / \mathrm{m}^{3}$.day. Therefore, further studies need to increase the influent concentration of ammonia or nitrogen loading rate to evaluate the nitrogen removing ability of the PARBCR model.

Acknowledgements: This research is funded by Vietnam National University-HoChiMinh City (VNU-HCM) under grant number of C2016-24-05.

\section{Trang 14}




\section{Úng dụng quá trình kết hợp Nitrit hóa bán phần - Anammox sử dụng giá thể sinh học quay để xử lý nước thải giàu ammonium}

Nguyễn Như Hiển ${ }^{1}$, Trương Thị Thanh Vân ${ }^{2}$, Lê Thanh Sơn, Phan Thế Nhật ${ }^{2}$, Nguyễn Phước Dân ${ }^{2}$.

${ }^{1}$ Viện Môi trường và Tài nguyên, Đại học Bách Khoa TP.HCM, Việt Nam

${ }^{2}$ Khoa Môi trường và Tài nguyên, Đại học Bách Khoa TP.HCM, Việt Nam

\section{TÓM TẮT}

Kết hơp quá trình Nitrit hóa bán phầnAnammox sủ dụng bể giá thể sinh học quay dạng mé (PARBC) để loại bỏ amonium trong nước thải được đánh giá trong nghiên cứu này. Việc tích luỹ sinh khối Anammox lên giá thể dễ dàng đạt được sau 5 mẻ (5 ngày) vận hành với nuớc thải nhân tạo. Sau đó sinh khối $A O B$ đuợc cấy vào mô hình $P A R B C$ nhằm hoàn thành việc kết hợp hai quá trình nitrit hoá bán phầnAnammox trong cùng một bể để xủ lý amonium.Sau 60 mẻ vận hành, tốc độ loại bỏ nito cao nhất đạt được là $0,33 \mathrm{~kg} \mathrm{~N} / \mathrm{m} 3$ úng với hiệu suất loại bỏ nito là $90 \%$ ở nồng độ ammonium đàu vào là $250 \mathrm{mg} \mathrm{N} / \mathrm{L}$. Hoạt tính của Anammox (SAA) của giá thể và bùn lo lưng trong bể đuoọc xác định là 0,298 $\mathrm{gN}$ N2/gVSS/ngày và 0,0041 gN-N2/gVSS/ngày. Hơn nữa nồng độ bùn trong bể PARBC đươc xác định là $17.765 \mathrm{mg} M L S S / L$. Kết quả này cho thấy vi khuẩn Anammox thich nghi và phát triển tốt trên giá thể sinh học quay, nguợc lại vi khuẩn Anammox hầu nhu không phát triển được ở dạng lo lưng trong bể. Nghiên cúu này cho thấy mô hình PARBCR có tiềm năng rất lớn để xủ lý nuớc thải giàu ammonium vói thòi gian khởi động mô hình thấp.

Tù khóa: Nitrit hóa bán phần, Anammox, PARBC, SAA

\section{TÀI LIỆU THAM KHẢO}

[1] Strous, M., Van Gerven, E., Zheng, P., Kuenen, J. G., \& Jetten, M. S., "Ammonium removal from concentrated waste streams with the anaerobic ammonium oxidation (anammox) process in different reactor configurations," Water Research, vol. 31, no. 8, pp. 1955-1962, 1997.

[2] Helmer, C., Tromm, C., Hippen, A., Rosenwinkel, K. H.,Seyfried, C. F. and Kunst, S., "Single stage nitrogen removal by nitritation and anaerobic ammonium oxidation in biofilm systems," Water Science Technology, vol. 43, pp. 311 - 320,
2000.

[3] Lieu, P.K. et al., "Single-stage nitrogen removal using anammox and partial nitritation (SNAP) for treatment of synthetic landfill leachate," Japanese Journal of Water Treatment Biology, vol. 41, no. 2, pp. 103-112, July 2005.

[4] Third K.A, A., Sliekers A.O., Kuenen J.G. , and Jetten M. S. M., "The CANON System (Completely Autotrophic Nitrogen-removal Over Nitrite) under Ammonium Limitation: Interaction and Competition between Three Groups of Bacteria," System. Appl. 
Microbiol, vol. 24, pp. 588 - 596, 2001.

[5] Nhat, P.T., Biec, H.N., Mai, N.T-M., Thanh, B.X., Dan, N.P., "Application of a partial nitritation and anammox system for the old landfill leachate treatment," International Biodeterioration \& Biodegradation, vol. 94, pp. 1 - 38, 2014.

[6] Van de Graaf, A. A., de Bruijn, P., Robertson, L. A., Jetten, M. S., \& Kuenen, J. G., "Autotrophic growth of anaerobic ammonium-oxidizing micro-organisms in a fluidized bed reactor," Microbiology, vol. 142, no. 8, pp. 2187-2196, March 1996.

[7] Dapena-Mora, A., Campos, J. L., Mosquera-Corral, A., \& Méndez, R., "Anammox process for nitrogen removal from anaerobically digested fish canning effluents," Water Science and Technology, vol. 53, no. 12, pp. 265-274, 2006.

[8] Dien, D.V. et al., "Application of Singlestage Nitrogen removal using Anammox and Partial nitritation (SNAP) for old landfill leachate treatment," Journal of Science and Technology (Vietnam), 2014.

[9] Vazquez-Padin, J. R., Pozo, M. J., Jarpa, M., Figueroa, M., Franco, A., MosqueraCorral, A.,. \& Mendez, R., "Treatment of anaerobic sludge digester effluents by the CANON process in an air pulsing SBR. Journal of Hazardous Materials," Journal of Hazardous Materials, vol. 166, no. 1, pp. 336-341, July 2009.

[10] Zhang, Z., Chen, S., Wu, P., Lin, L., \& Luo, H., "Start-up of the Canon process from activated sludge under salt stress in a sequencing batch biofilm reactor (SBBR). Bioresource Technology," Bioresource technology, vol. 101, no. 16, pp. 63096314, August 2010.

[11] Chang, X., Li, D., Liang, Y., Yang, Z., Cui, S., Liu, T.,. \& Zhang, J., "Performance of a completely autotrophic nitrogen removal over nitrite process for treating wastewater with different substrates at ambient temperature," Journal of Environmental Sciences, vol. 25, no. 4, pp. 688-697, April 2013.

[12] Qiao, S., Nishiyama, T., Fujii, T., Bhatti, Z., \& Furukawa, K., "Rapid startup and high rate nitrogen removal from anaerobic sludge digester liquor using a SNAP process," Biodegradation, vol. 23, no. 1, pp. 157-164, February 2012. 